\title{
ANTIFUNGAL SUSCEPITIBILITY PROFILE OF CANDIDA SPP. ORAL ISOLATES OBTAINED FROM DENTURE WEARERS
}

\author{
Lyon J.P. ${ }^{1 *}$; Moreira L.M. ${ }^{1}$; Cardoso, M.A.G. ${ }^{1}$; Saade J. ${ }^{1}$; Resende M.A. ${ }^{2}$ \\ ${ }^{1}$ Instituto de pesquisa e Desenvolvimento da Universidade do Vale do Paraíba, São José dos Campos, SP, Brasil; ${ }^{2}$ Instituto de \\ Ciências Biológicas da Universidade Federal de Minas Gerais, Belo Horizonte, MG, Brasil
}

Submitted: December 05, 2007; Returned to authors for corrections: March 09, 2008; Approved: November 02, 2008.

\begin{abstract}
Denture stomatitis is an inflammatory condition that occurs in denture wearers and is frequently associated with Candida yeasts. Antifungal susceptibility profiles have been extensively evaluated for candidiasis patients or immunosupressed individuals, but not for healthy Candida carriers. In the present study, fluconazole, itraconazole, voriconazole, terbinafine and 5-flucytosin were tested against 109 oral Candida spp. isolates. All antifungal agents were effective against the samples tested except for terbinafine. This work might provide epidemiological information about Candida spp. drug susceptibility in oral healthy individuals.
\end{abstract}

Key words: Denture wearers, Candida carriage, normal oral mucosa, Antifungal agents

\section{INTRODUCTION}

Denture stomatitis is an inflammatory condition that frequently occurs in the palate of denture wearers. This pathology is usually associated with Candida yeasts $(1,12,19)$. The most common treatment for the disturbance is the application of topical nistatin in multiple daily doses, what reflects in poor patient cooperation. Besides, the occurrence of recurrent disease is very common. With the discovery of triazolic antifungal drugs for systemic use, fluconazole and itraconazole emerged as alternative treatments. The use of fluconazole has demonstrated promising results; however, there are few therapeutic studies about the application of itraconazole for the treatment of denture stomatitis (6).

Other antifungal agents are also important for fungal infection treatment, however, not usually employed in the treatment of oral candidiasis. For instance, terbinafine is an antifungal agent, belonging to the allylamines group, which presents a potent in vitro activity against a number of filamentous and dimorphic fungi. Some authors have proposed the application of this agent against Candida yeasts (9), although, its ability in inhibit yeasts is still controversial. Other antifungal agents, such as amphotericin B, 5-flucytosine and voriconazole have a proved action against Candida spp., and are used for the treatment of invasive candidiasis.

Several studies focusing on the susceptibility of Candida spp. have been developed using samples obtained from immunosupressed individuals or individuals presenting candidiasis. However, the prevalence of Candida spp. resistant to antifungals has not been extensively studied among healthy Candida spp. carriers. The evaluation of the susceptibility profile of Candida spp. isolated from the oral cavity of healthy denture wearers and dentate individuals will provide additional information about this topic.

\section{MATERIALS AND METHODS}

A total of 112 subjects who had worn complete removable dentures for at least one year and 103 subjects with natural teeth were recruited from the Dental School of the Federal University of Minas Gerais (UFMG), Brazil, and from the Dental School of the Federal University of Alfenas (UNIFAL), Brazil. All the subjects were HIV negative, never presented malignant processes and were not under antimycotic therapy in the moment of the sampling. Samples were collected from the dorsum of the tongue with a sterilized swab. Before the

*Corresponding Author. Mailing address: Instituto de Pesquisa e Desenvolvimento da Universidade do Vale do Paraíba, São José dos Campos-SP, Brasil. Av. Shishima Hifumi, 2911 Zip Code: 12244-000, Bairro Urbanova, São José dos Campos, SP. Phone (12) 3947-1135. E-mail: julianalyon@univap.br 
collection, 109 samples were obtained, comprising $71 \mathrm{C}$. albicans, 15 C. glabrata, 12 C. tropicalis, eight $C$. parapsilosis and three $C$. krusei. Samples were identified through zymogram, auxanogram, gem tube formation test, growth at $45^{\circ} \mathrm{C}$ and microcultive (Kurtzman and Fell, 1994).

Amphotericin B (Sigma Chemical Co., St. Louis, USA), 5flucytosine (Hoffman La Roche, Bale, Switzerland), fluconazole (Pfizer São Paulo, Brazil), itraconazole (Janssen Pharmaceutica, Beerse, Belgium), voriconazole (Pfizer, São Paulo, Brazil), and terbinafine (Novartis Biociências S.A., São Paulo, Brazil) were obtained as reagent grade powders from their respective manufacturers. Stock solutions were prepared in dimethylsulphoxide (itraconazole, amphotericin B, terbinafine and voriconazole) or water (fluconazole and 5-flucytosine). Serial two fold dilutions were prepared exactly as outlined in CLSI document M 27-A (15). Final dilution were made in RPMI 1640 medium (Sigma, St Louis, Mo, USA) buffered to $\mathrm{pH} 7$ with $0,165 \mathrm{M}$ morpholinepropane sulphonic acid (MOPS) buffer (Sigma). Aliquots (100ml) of each agent at a two fold final concentration were dispensed into the wells of plastic microdilution trays. The trays were sealed and frozen at $-70^{\circ} \mathrm{C}$ until they were used, except for amphotericin B that was prepared in the moment of use.

Broth microdilution testing was performed in accordance with the guidelines in the CLSI document M27-A (15). The inoculum suspension was prepared by the spectrophotometric method of inoculum preparation, with a final inoculum of $1.5 \pm$ $1.0 \times 10^{3}$ cells $/ \mathrm{ml}$. The final concentration of the antifungal agents was 0.3 to $64.0 \mathrm{mg} / \mathrm{ml}$ for amphotericin B, fluconazole, voriconazole and terbinafine, 0.12 to $256 \mu \mathrm{g} / \mathrm{ml}$ for 5 -flucytosine and 0.02 to $25.0 \mu \mathrm{g} / \mathrm{ml}$ for itraconazole. The trays were incubated at $35^{\circ} \mathrm{C}$ and MIC (Minimum Inhibitory Concentration) endpoints were read after $48 \mathrm{~h}$ of incubation. Drug free and yeast controls were included.

Following incubation, the MICs of fluconazole, terbinafine, voriconazole and itraconazole were read as the lowest concentration at which prominent decrease in turbidity relative to the growth control was observed (decrease of $80 \%$ in turbidity). For amphotericin B and 5-flucytosine, MIC was considered as the complete inhibition of growth. Quality control was ensured by testing the CLSI recommended strain $C$. parapsilosis ATCC 22019. All the tests were performed in triplicate. The interpretative breakpoints were the following:

- Fluconazole: Susceptibile if MIC $\leq 8 \mu \mathrm{g} / \mathrm{ml}$; Susceptibile dose-dependent if MIC was between 16 to $32 \mu \mathrm{g} / \mathrm{ml}$; Resistant if MIC $\geq 64 \mu \mathrm{g} / \mathrm{ml}(15,22)$.

- Itraconazole: Susceptibile if MIC $\leq 0.125 \mu \mathrm{g} / \mathrm{ml}$; Susceptibile dose-dependent if MIC was between 0.25 to $0.5 \mu \mathrm{g} / \mathrm{ml}$; Resistant if MIC $\geq 1 \mu \mathrm{g} / \mathrm{ml}(15,22)$.

- 5-flucytosine: Susceptibile if MIC $\leq 4 \mu \mathrm{g} / \mathrm{ml}$; Intermediary if MIC was between 8 to $16 \mu \mathrm{g} / \mathrm{ml}$; Resistant if MIC $\geq 32 \mu \mathrm{g} /$ $\mathrm{ml}(15,22)$
Although no breakpoints have beeen established for amphotericin $\mathrm{B}$, terbinafine and voriconazole, the following values were used as reference:

- Amphotericin B: Resistant if MIC > $1 \mu \mathrm{g} / \mathrm{ml}(15)$

- Voriconazole: Resistant if MIC > $1 \mu \mathrm{g} / \mathrm{ml}$ (18)

- Terbinafine: Resistant if MIC > $1.4 \mu \mathrm{g} / \mathrm{ml}$ (24)

\section{RESULTS}

In the present study, $90 \%$ of $C$. albicans, C. parapsilosis and $C$. tropicalis isolates were inhibited by fluconazole at a concentration of $2.0 \mu \mathrm{g} / \mathrm{ml}$. There was no difference between the samples obtained from denture wearers and from patients with natural teeth. Considering $C$. glabrata samples, $\mathrm{MIC}_{90}$ (inhibition of $90 \%$ of the isolates) reached $8.0 \mu \mathrm{g} / \mathrm{ml}$ for samples obtained from denture wearers and in the totality of the samples. Regarding C. krusei, resistance was observed among the isolates.

Itraconazole demonstrated a good performance against $C$. albicans $\left(\mathrm{MIC}_{90}=0.06 \mu \mathrm{g} / \mathrm{ml}\right), C$. parapsilosis, $C$. krusei and $C$. tropicalis $\left(\mathrm{MIC}_{90}=0.03 \mu \mathrm{g} / \mathrm{ml}\right.$ ). Among the isolates obtained from denture wearers, $\mathrm{MIC}_{90}$ for $C$. glabrata was $0.05 \mu \mathrm{g} / \mathrm{ml}$, being considered susceptible dose-dependents. However, $\mathrm{MIC}_{90}$ for itraconazole was $0.12 \mu \mathrm{g} / \mathrm{ml}$ for the isolates obtained from individuals with natural teeth and for the totality of the samples.

Voriconazole was highly efficient against all the isolates tested, with $\mathrm{MIC}_{90}$ of $1.0 \mu \mathrm{g} / \mathrm{ml}$. Similarly, amphotericin B presented $\mathrm{MIC}_{90}$ of $1.0 \mu \mathrm{g} / \mathrm{ml}$ for all species studied, considering both samples obtained from denture wearers and from individuals with natural teeth. All of the isolates were also considered susceptible to 5-flucytosine. On the other hand, terbinafine showed high MIC values for all species evaluated $\left(\mathrm{MIC}_{90} \geq 64.0 \mu \mathrm{g} / \mathrm{ml}\right.$ ), except for $C$. parapsilosis isolated from individuals with natural teeth, with $\mathrm{MIC}_{90}$ of $2.0 \mu \mathrm{g} / \mathrm{ml}$. Results are expressed on Table 1.

\section{DISCUSSION}

The present study provides the susceptibility profile of Candida spp. samples obtained from healthy individuals, with no signs of oral candidiasis. Several studies have reported the prevalence and antifungal susceptibility testing in individuals with oral candidiasis manifestations $(2,4,10,14)$, but only a few studies have focused on samples obtained from Candida carriers without signs of infection (21).

The prevalence of Candida spp in the oral cavity of denture wearers is considerably greater than in individuals with natural teeth (13), even considering that the presence of the yeast does not implicates in the manifestation of disease. Both groups were compared regarding the susceptible profile and no significant differences were recorded for the antifungal agents tested, 
Table 1. Minimum Inhibitory concentration (MIC) in $\mu \mathrm{g} / \mathrm{ml}$ obtained for Candida species obtained from denture wearers and from individuals with natural teeth.

\begin{tabular}{|c|c|c|c|c|c|c|c|}
\hline \multirow{2}{*}{ Antifungal agent } & \multirow{2}{*}{ Species } & \multicolumn{2}{|c|}{$\begin{array}{c}\text { Denture wearers } \\
\text { without signs of candidiasis }\end{array}$} & \multicolumn{2}{|c|}{$\begin{array}{l}\text { Healthy individuals } \\
\text { with natural teeth }\end{array}$} & \multicolumn{2}{|c|}{$\begin{array}{c}\text { Total of } \\
\text { individuals }\end{array}$} \\
\hline & & $\begin{array}{l}\operatorname{MIC}_{90} \\
(\mu \mathrm{g} / \mathrm{ml})\end{array}$ & $\begin{array}{c}\text { MIC } \\
\text { Range }\end{array}$ & $\begin{array}{r}\mathrm{MIC}_{90} \\
(\mu \mathrm{g} / \mathrm{ml})\end{array}$ & $\begin{array}{l}\text { MIC } \\
\text { Range }\end{array}$ & $\begin{array}{l}\mathrm{MIC}_{90} \\
(\mu \mathrm{g} / \mathrm{ml})\end{array}$ & $\begin{array}{l}\text { MIC } \\
\text { Range }\end{array}$ \\
\hline \multicolumn{8}{|l|}{ Fluconazole } \\
\hline & C. albicans & $2.0^{\mathrm{a}}$ & $0.25-64.0$ & $2.0^{\mathrm{a}}$ & $0.25-4.0$ & $2.0^{\mathrm{a}}$ & $0.25-64.0$ \\
\hline & C. glabrata & $8.0^{\mathrm{d}}$ & $1.0-16.0$ & $4.0^{\mathrm{a}}$ & $0.5-8.0$ & $8.0^{\mathrm{d}}$ & $0.5-16.0$ \\
\hline & C. parapsilosis & $1.0^{\mathrm{a}}$ & $1.0-64.0$ & $4.0^{\mathrm{a}}$ & $1.0-4.0$ & $4.0^{\mathrm{a}}$ & $0.25-4.0$ \\
\hline & C.krusei & $64.0^{\mathrm{d}}$ & $32.0-64.0$ & $64.0^{\mathrm{d}}$ & 64.0 & $64.0^{\mathrm{d}}$ & $32.0-64.0$ \\
\hline & C. tropicalis & $2.0^{\mathrm{a}}$ & 2.0 & $1.0^{\mathrm{a}}$ & 1.0 & $2.0^{\mathrm{a}}$ & $1.0-2.0$ \\
\hline \multicolumn{8}{|l|}{ Itraconazole } \\
\hline & C. albicans & $0.06^{\mathrm{a}}$ & $0.03-1.0$ & $0.06^{\mathrm{a}}$ & $0.03-0.5$ & $0.06^{\mathrm{a}}$ & $0.03-1.0$ \\
\hline & C. glabrata & $0.5^{\mathrm{a}}$ & $0.06-0.5$ & $0.12^{\mathrm{a}}$ & $0.03-0.5$ & $0.12^{\mathrm{a}}$ & $0.03-0.5$ \\
\hline & C. parapsilosis & $0.03^{\mathrm{a}}$ & $0.03-0.06$ & $0.03^{\mathrm{a}}$ & $0.03-0.06$ & $0.03^{\mathrm{a}}$ & $0.03-0.06$ \\
\hline & C. krusei & $0.03^{\mathrm{a}}$ & $0.03-0.06$ & $0.03^{\mathrm{a}}$ & $0.03-0.12$ & $0.03^{\mathrm{a}}$ & $0.03-0.12$ \\
\hline & C. tropicalis & $0.03^{\mathrm{a}}$ & $0.03-0.12$ & $0.03^{\mathrm{a}}$ & $0.03-0.25$ & $0.03^{\mathrm{a}}$ & $0.03-0.25$ \\
\hline \multicolumn{8}{|l|}{ Voriconazole } \\
\hline & C. albicans & $0.25^{\mathrm{a}}$ & $0.12-64.0$ & $0.5^{\mathrm{a}}$ & $0.12-2.0$ & $0.25^{\mathrm{a}}$ & $0.12-64.0$ \\
\hline & C. glabrata & $1.0^{\mathrm{a}}$ & $0.12-16.0$ & $0.12^{\mathrm{a}}$ & 0.12 & $1.0^{\mathrm{a}}$ & $0.12-16.0$ \\
\hline & C. parapsilosis & $0.5^{\mathrm{a}}$ & $0.12-0.5$ & $0.5^{\mathrm{a}}$ & $0.25-1.0$ & $0.5^{\mathrm{a}}$ & $0.12-1.0$ \\
\hline & C. krusei & $0.12^{\mathrm{a}}$ & $0.5-1.0$ & $1.0^{\mathrm{a}}$ & 1.0 & $1.0^{\mathrm{a}}$ & $0.5-1.0$ \\
\hline & C. tropicalis & $0.12^{\mathrm{a}}$ & 0.12 & $0.12^{\mathrm{a}}$ & 0.12 & $0.12^{\mathrm{a}}$ & 0.12 \\
\hline \multicolumn{8}{|c|}{ Anphotericin B } \\
\hline & C. albicans & $1.0^{\mathrm{a}}$ & $0.25-2.0$ & $1.0^{\mathrm{a}}$ & $0.25-1.0$ & $1.0^{\mathrm{a}}$ & $0.25-2.0$ \\
\hline & C. glabrata & $1.0^{\mathrm{a}}$ & $0.5-32.0$ & $0.5^{\mathrm{a}}$ & $0.12-8.0$ & $1.0^{\mathrm{a}}$ & $0.5-32.0$ \\
\hline & C. parapsilosis & $0.25^{\mathrm{a}}$ & $0.25-0.5$ & $0.5^{\mathrm{a}}$ & $0.25-2.0$ & $0.5^{\mathrm{a}}$ & $0.25-2.0$ \\
\hline & C. krusei & $0.5^{\mathrm{a}}$ & 0.5 & $1.0^{\mathrm{a}}$ & 1.0 & $1.0^{\mathrm{a}}$ & $0.5-1.0$ \\
\hline & C. tropicalis & $0.25^{\mathrm{a}}$ & $0.25-1.0$ & $0.25^{\mathrm{a}}$ & $0.25-0.5$ & $0.25^{\mathrm{a}}$ & $0.25-1.0$ \\
\hline \multicolumn{8}{|l|}{ 5-Flucytosine } \\
\hline & C. albicans & $1.0^{\mathrm{a}}$ & $0.5-264$ & $1.0^{\mathrm{a}}$ & $0.5-32$ & $1.0^{\mathrm{a}}$ & $0.5-264$ \\
\hline & C. glabrata & $1.0^{\mathrm{a}}$ & $0.5-1.0$ & $1.0^{\mathrm{a}}$ & $0.5-8.0$ & $1.0^{\mathrm{a}}$ & $0.5-8.0$ \\
\hline & C. parapsilosis & $0.5^{\mathrm{a}}$ & $0.5-264$ & $0.5^{\mathrm{a}}$ & 0.5 & $0.5^{\mathrm{a}}$ & $0.5-264$ \\
\hline & C. krusei & $0.5^{\mathrm{a}}$ & $0.5-4.0$ & $0.5^{\mathrm{a}}$ & 0.5 & $0.5^{\mathrm{a}}$ & $0.5-4.0$ \\
\hline & C. tropicalis & $0.5^{\mathrm{a}}$ & 0.5 & $0.5^{\mathrm{a}}$ & $0.5-4.0$ & $0.5^{\mathrm{a}}$ & $0.5-4.0$ \\
\hline \multicolumn{8}{|l|}{ Terbinafine } \\
\hline & C. albicans & 64.0 & $2.0-64.0$ & 64.0 & $2.0-64.0$ & 64.0 & $2.0-64.0$ \\
\hline & C. glabrata & 64.0 & $1.0-64.0$ & 64.0 & $1.0-64.0$ & 64.0 & $1.0-64.0$ \\
\hline & C. parapsilosis & 64.0 & $4.0-64.0$ & 64.0 & $4.0-64.0$ & 64.0 & $4.0-64.0$ \\
\hline & C. krusei & 64.0 & 64.0 & 64.0 & 64.0 & 64.0 & 64.0 \\
\hline & C. tropicalis & 64.01 & 64.0 & 2.0 & 2.0 & 64.0 & 64.0 \\
\hline
\end{tabular}

${ }^{\text {a }}$ Susceptible, ${ }^{\mathrm{b}}$ Susceptible dose-dependent, ${ }^{\mathrm{c}}$ Intermediate, ${ }^{\mathrm{d}}$ Resistant; $\mathrm{MIC}_{90}=$ Inhibition of $90 \%$ of the isolates.

except for itraconazole and for fluconazole against $C$. glabrata. The continued exposure of Candida yeasts to antifungals in certain patient groups has already been shown to alter the susceptibility of strains $(10,20)$. Besides, the treatment with antifungal agents might lead to the selection of non-albicans
Candida species. The development of resistance mechanisms is common, especially with C. glabrata, and C. krusei is intrinsically resistant to fluconazole.

Patients were inquired about the use of antifungal agents and only those who reported not to be under antifungal therapy 
were included in the study. However, due to the high incidence of denture stomatitis among denture wearers, this variable is difficult to control. Patients might have a history of antifungal use or ever unknown the name or function of a medicine prescribed.

Despite most antifungal drugs tested in the present article are not available for oral administration, data about the susceptibility profile against oral isolates provides epidemiological evidences and might be helpful in guidelines clinical practice. Besides, formulations can be developed for these agents due to the great seek for new forms of antifungal therapy. On the other hand, oral microorganisms can be responsible for spread infection or severe oral candidiasis if an individual became susceptible, In this case, the profile of susceptibility could be extrapolated.

As it could be expected, fluconazole demonstrated great efficacy against $C$. albicans, $C$. parapsilosis and $C$. tropicalis isolates. On the other hand, $C$. krusei and $C$. glabrata were resistant to this drug. These results are consistent to those reported by several authors $(8,23,26)$. On the other hand, itraconazole demonstrated a surprisingly low efficacy against C. albicans isolates. C. glabrata were also resistant to this drug, what had been already reported by Pfaler et al. (18) and Swoboda-Kopec (27). Considering the higher prevalence of $C$. albicans among denture stomatitis patients, these results disagree with Cross et al. (6) affirmative regarding the efficacy of itraconazole for the treatment of this pathologic condition. However, it is important to notice that, unlike the referred work, clinical trials were not developed in the present study.

Results obtained in the present study were consistent with those obtained by Wingeter et al. (28) regarding the susceptibility of oral isolates to amphotericin B. According to Ghannoum and Rice (7), resistance to polyenic antifungal agents is rare. The most common treatment of denture stomatits is the use of nystatin, a polyene antifungal agent.

Burn et al. (3) found elevate MIC values for voriconazole against $C$. glabrata isolated from head irradiated patients. However, in the present study, this drug demonstrated high efficacy against $C$. glabrata strains. About this discrepancy, we can argue that endpoints are not well established for this drug. Besides, the group of patients was different and only a small number of strains were evaluated in the present work. Other researchers found susceptibility profiles to voriconazole similar to those represented in this article.

Unlike results obtained by Jessup et al. (9) and Ryder et al. (26), who obtained good results for terbinafine against Candida spp. isolates, several authors have reported that this drug does not present significant in vitro activity against Candida yeasts $(17,25)$. These finds are corroborated by the present study. Furthermore, good activity against $C$. parapsilosis and poor efficacy against other Candida species is a common report (16). According to Ryder et al. (26), poor results obtained with terbinafine against Candida yeasts in vitro are not corroborate by clinical trials where this drug has proven to be effective. These authors suggest that a buffer (MOPS) should be added to the culture medium since terbinafine is less effective under low $\mathrm{pH}$ conditions.

The present study reported the susceptibility profile of Candida yeasts isolated from the oral cavity of healthy individuals. We can conclude that the overall outcome was very satisfactory for the antifungal drugs tested, with exception of terbinafine. This work might provide epidemiological information about Candida spp. drug susceptibility in oral healthy individuals.

\section{RESUMO}

\section{Perfil de sensibilidade antifungica de isolados de candida sp obtidos de usuários de prótese total}

A estomatite protética é uma condição inflamatória que ocorre em usuários de prótese total e está frequentemente associada a leveduras do gênero Candida, Os perfis de suscetibilidade a antifúngicos têm sido extensivamente estudados em pacientes com candidíase ou em indivíduos imunossuprimidos, mas não em portadores sadios de Candida. No presente estudo, fluconazol, itraconazol, voriconazol, terbinafina e 5-flucitosina foram testados contra 109 isolados orais de Candida spp. Todos os agentes antifúngicos mostraram-se eficazes contra as amostras avaliadas, exceto a Terbinafina. $\mathrm{O}$ presente trabalho pode fornecer dados epidemiológicos com relação à susceptibilidade a antifúngicos de Candida spp em indivíduos com saúde oral.

Palavras-chave: Usuários de prótese total, Portadores de Candida, Mucosa oral normal, agentes antifúngicos

\section{ACKNOWLEDGEMENTS}

We thank to CNPq for the financial support.

\section{REFERENCES}

1. Barbeau, J.; Séguin, J.; Goulet, J.P; Koninck, L.; Avon, S.L.; Lalonde, B.; Rompré, P.; Deslauriers, N. (2003). Reassessing the presence of Candida albicans in denture related stomatitis. Oral Surg. Oral Med. Oral Pathol. Oral Radiol. Endodont., 95, 51-59.

2. Belazi, M.; Velegraki, A.; Koussidou-Eremondi, T.; Andreadis, D.; Hini, S.; Arsenis, G.; Eliopoulou, C.; Destouni, E.; Antoniades, D. (2004) Oral Candida isolates in patients undergoing radiotherapy for head and neck cancer: prevalence, azole susceptibility profiles and response to antifungal treatment. Oral Microbiol. Immunol., 19, 347-351.

3. Burn, K.A.; Fothergill, A.W.; Kirkpatrick, W.R.; Coco, B.J.; Patterson, T.F.; McCarthy, D.I.; Rinaldi, M.G.; Redding, S.W. (2004). Comparison of Antifungal Susceptibilities to Fluconazole and Voriconazole of Oral Candida glabrata Isolates from Head and Neck Radiation Patients. J. Clin. Microbiol., 42, 5846-5848. 
Lyon, J.P. et al.

4. Costa, C.R.; de Lemos, J.A.; Passos, X.S.; de Araújo, C.R.; Cohen, A.J.; Souza, L.K.; Silva, M.R.R. (2006). Species distribution and antifungal susceptibility profile of oral Candida isolates from HIVinfected patients in the antiretroviral therapy era. Mycopathologia. $162,45-50$.

5. Cross, L.J.; Bagg, J.; Wray, D.; Aitchison, T. (1998). A comparison of fluconazole and itraconazole in the management of denture stomatitis: A pilot study. J. Dentist., 26, 657-664.

6. Cross, L.J.; Willians, D.W.; Sweeney, C.P.; Jackson, M.S.; Lewis, M.A.O.; Bagg, J. (2004). Evaluation of the recurrence of denture stomatitis and Candida colonization in a small group of patients who received itraconazole. Oral Surg. Oral Med. Oral Pathol. Oral Radiol. Endodont., 97, 351-358.

7. Ghannoum, M.A.; Rice, L.B. (1999). Antifungal agents: Mode of action, mechanisms of resistance, and correlation of these mechanisms with bacterial resistance. Clin. Micobiol. Rev., 12, 50117 .

8. Haberland-Carrodeguas, C.; Allen, C.M.; Beck, F.M.; Bueschiling, W.J.; Koletar, S.L.; Sundstron, P. (2002). Prevalence of fluconazoleresistant strains of Candida albicans in otherwise healthy outpatients. J.Oral Pathol. Med., 31, 99-105.

9. Jessup, C.J.; Ryder, N.S.; Ghannoum, M.A. (2000). An evaluation of the in vitro activity of Terbinafine. Med. Mycol., 38, 155-159.

10. Kuriyama, T.; Williams, D.W.; Bagg. J.; Coulter, W.A.; Ready, D.; Lewis, M.A.O. (2005). In vitro susceptibility of oral Candida to seven antifungal agents. Oral Microbiol. Immunol., 20, 349-353.

11. Kurtzman, P.C.; Fell, J.W. (1998). The yeasts: a taxonomic study. Amsterdam: Elsevier.

12. Lanfon, H.; Al-Karaawi, Z.; Mc Collough, M.; Porter, S.R.; Pratten, J. (2005). Composition of in vitro denture plaques biofilms and susceptibility to antifungal. FEMS Microbiol. Lett., 242, 345-341.

13. Lyon, J.P.; Costa, S.C.; Totti, V.M.G.; Munhoz, M.F.; Resende, M.A. (2006). Predisposing conditions for Candida spp. carriage in the oral cavity of denture wearers and individuals with natural teeth. Canadian J. Microbiol., 52, 462-467.

14. Manfredi, M.; McCullough, M.J.; Polonelli, L.; Conti, S.; Al-Karaawi, Z.M.; Vescovi, P.; Porter, S.R. (2006). In vitro antifungal susceptibility to six antifungal agents of 229 Candida isolates from patients with diabetes mellitus. Oral Microbiol Immunol., 21, 177-82.

15. National Commitee for Clinical Laboratory Standards (2002). Reference method for broth dilution antifungal susceptibility testing of yeasts. Approved standard (NCCLS document M27-A2) Villanova, PA: National Committee for Clinical Laboratory Standards.

16. Perea S, Gonzalez G, Fothergill, AW, Sutton, DA, Rinaldi, MG (2002). In vitro activities of terbinafine in combination with fluconazole, voriconazole and posaconazole against clinical isolates of Candida glabrata with decreased susceptibility to azoles. J. Clin. Microbiol., 40: 1831-1833.

17. Petranyi, G.; Meingassner, J.G.; Mieth, H. (1987). Antifungal activity of the allylamine derivative Terbinafine in vitro. Antimicrob. Agents Chemother., 31, 1365-1368.

18. Pfaller, M.A.; Diekema, D.J.; Messer, S.A.; Boyken, S.; Hollis, R.J.; Jones, R.N. (2003). In vitro activities of Voriconazole, Posaconazole, and four licensed systemic antifungal agents against Candida species infrequently isolated from blood. J.Clin. Microbiol., 41, 78-83, 2003.

19. Ramage, G.; Tomsett, K.; Wichers, B.L.; Lopez-Ribot, J.L.; Redding, S.W. (2004). Denture stomatitis: A role for Candida biofilms. Oral Surg. Oral Med. Oral Pathol. Oral Radiol. Endodont., 98, 53-59.

20. Rautemaa, R.; Richardson, M.; Pfaller, M.; Koukila-Kähkölä, P.; Perheentupa, J.; Saxén, H. (2007). Decreased susceptibility of Candida albicans to azole antifungals: a complication of long-term treatment in autoimmune polyendocrinopathy-candidiasisectodermal dystrophy (APECED) patients. J. Antimicrob Chemother., 60, 889-892.

21. Resende, M.A.; Souza, L.V.N.F; Oliveira, R.C.B.W.; Koga-Ito, C.Y.; Lyon, J.P. (2006). Prevalence and antifungal susceptibility of yeasts obtained from the oral cavity of elderly individuals. Mycopathologia, 162, 39-44.

22. Rex, J.H.; Pfaller, M.A.; Walsh, T.J.; Chaturvedi, V.; Espinel-Ingroff, A.; Ghannoum, M,A,; Gosey, L.L.; Odds, F,C.; Rinaldi, M.G.; Sheehan, D.J.; Warnock, D.W. (2001). Antifungal susceptibility testing: Pratical aspects and current challenges. Clin. Microbiol. Rev., 14, 643-658.

23. Rubio Calvo, M.C.; Gil, J.; De Ocaris, I.R.; Benito, R.; Rezusta, A. (2003). In vitro activity of fluconazole, voriconazole and posaconazole against Candida spp. Rev. Espanol. Quimioter, 16, 227-232.

24. Ryder, N.S. (1999) Activity of terbinafine against serious fungal pathogens. Mycoses, 42, 115-119.

25. Ryder, N.S.; Favre, B. (1997). Antifungal activity and mechanism of action of Terbinafine. Pharmacotherapy, 8, 275-287.

26. Ryder, N.S.; Wagner, S.; Leitner, I. (1998). In Vitro Activities of Terbinafine against Cutaneous Isolates of Candida albicans and Other Pathogenic Yeasts. Antimicrob. Agent. Chemother., 42, 10571061 .

27. Swoboda-Kopec, E.; Wroblewska, M.; Rokosz, A.; Krawezyk, E.; Luczac, M. (2003). Susceptibility of clinical isolates of Candida glabrata to new triazoles. Int. J. Antimicrob. Agents, 21, 360-361.

28. Winterger, M.A.; Guilhermetti, E.; Shinobu, C.S.; Takaki, I.; Svidzinski, I.E. (2007). Microbiological identification and in vitro sensitivity of Candida. Rev. Soc. Bras. Med. Trop., 40, 272-276. 